McQuillan, Martin (2016) Clarity and Doubt: Derrida Among the Palestinians. Paragraph, 39(2), pp. 220-237. ISSN (print) 0264-8334

This article has been accepted for publication by Edinburgh University Press in Paragraph.

http://www.euppublishing.com/doi/10.3366/para.2016.0196 


\section{Clarity and Doubt: Derrida Among the Palestinians}

In the right hand column of Glas, Derrida offers the following paragraphs:

Not to arrest the career of a Genet. For the first time I am afraid, while writing, as they say 'on' someone, of being read by him. Not to arrest him, not to draw him back, not to bridle him. Yesterday he let me know that he was in Beirut, among the Palestinians at war, encircled outcasts. I know that what interests me always takes (its/his) place over there, but how to show that? [Je sais que ce qui m'intéresse a toujours (son) lieu làbas, mais comment le montrer?] He almost never writes anymore, he has interred [enterré] literature like no one, he leaps [saute] wherever that explodes [ça saute] in the world, wherever the absolute knowledge of Europe takes a blow [coup], and these (hi)stories of glas, seing, flower, horse ought to make him shit.

How right he is. This is what I want to show by deporting you as swiftly as possible to the limits of a basin, a sea, where there arrive for an interminable war the Greek, the Jew, the Arab, the Hispano-Moor. Which I am also (following), by the trace [Que je suis aussi, à la trace]. ${ }^{1}$

Writing in 1974 in the year that the Arab League recognized the PLO as the 'sole, legitimate representative of the Palestinian people', just 12 months after the Yom Kippur War, and with memories of the Black September of 1970 still fresh in the 
memory, these paragraphs carry a certain weight and interest for us today, if we seek to address the question: what remains of Glas? Genet's engagement with the question of Palestine is well known, and recovered in his final work Prisoner of Love ${ }^{2}$, while the question of the Jew is a massively legible stake in the left-hand column of Glas and the wider corpus of Derrida, along with the philosophical memes of, say, sovereignty, the nation-state, the Abrahamic, Europe, sacrifice and so on. In this decisive moment of autobiographical concentration from 1974 we can see how the text of Glas might be said to inhabit and irrigate the entire text of Derrida and how within that the queerest of Derrida's friendships, the one with Genet, opens out onto the wider concerns of Derrida's thought and writing.

It is in this context that I would like to interrogate Derrida's own question in this passage: 'I know that what interests me always takes (its/his) place over there, but how to show that?' What does it mean for Derrida to offer such a sentence: 'what interests me' [his philosophical and political interests?] always [without fail or exception?] takes (its/his) place over there'? The French pronoun son offers both possibilities that what interests Derrida always takes place over there, and, what interests Derrida always happens to Genet among the Palestinians. It may be more normative to read the phrase as 'takes its place’ but Derrida's own parenthesis insists on the alternative. But how would one begin to show that? One could choose to demonstrate it through a set of textual and biographical references, say, or, one could choose to find another method for thinking through the Derrida-Genet relation and the Derrida-Genet-Palestine-Israel relation, without arresting it, without drawing it back or retarding its progress or shackling it with a bridle for some other utilitarian or preprogrammed purpose. How might it be possible in reading this passage to resist the 
impulse to put the Genet back in the bottle and to inter it, neither as a prisoner of love nor buried under ground in a grave or a cave of wonders? How to interrogate the question without interring it?

One legitimate strategy would be the elaboration of a personal history as an act of critical biography which laid out the facts of the interaction between Genet and Derrida, such as those offered by Edward Said in his essay on Genet's late writing: I recall that once during the evening he [Genet] said something very positive and surprisingly warm about Jacques Derrida-'un copain,' remarked Genet—whom I had thought of as a quietist Heideggerian type at the time; Glas had not yet been published, and it was only six months later, when Mariam, our little son, and I spent a few weeks in Paris in April 1973, that I learned from Derrida himself that his friendship with Genet had been sealed as the two of them watched soccer matches together. $^{3}$

In his biography of Genet, Edmund White notes that at this time Genet was dating a Moroccan soccer player who played for a French team, and whose career he followed with keen interest. White also recounts that in the Spring of 1972 Genet had attempted, unsuccessfully, 'to put together a book devoted to the Palestinian revolution, to be written collectively by Philippe Sollers, Jacques Henric, Paule Thévenin, Roland Barthes, Juan Goytisolo, Pierre Goyotat and Jacques Derrida. Genet's idea was that all these men would go to the Middle East for a while, and then write a book about their experiences'. ${ }^{4}$ This exercise in collective 'method writing' did not happen but its possibility is suggestive of Derrida's interest in the place of 
Palestine and Genet’s activities there, 'il saute partout où ça sauté dans le monde’, one of those places of the world that is 'jumping'.

An exercise such as this would have its value and should be pursued. However, the wording of these paragraphs in Glas point towards another horizon. The question is not necessarily whether Derrida agreed with all of Genet's positions or if his activities among the Palestinians mapped exactly onto Derrida's interests. In this sense we must ask, what is an interest? There is a difference between the things that are interesting to me and the things that are my interests, my vested interests and things that are in my best interest. Which of these register of interests, these special interests, these rates of interest, are referred to here in the sentence: 'I know that what interests me always takes (its/his) place over there.' Benoit Peeters writes in his biography of Derrida’s interest in Israel-Palestine:

Derrida wrote to [Levinas] on 6 June 1967, just after the outbreak of what would soon be called the Six-Day War. 'Glued to the radio' since the start of the conflict, he admitted that he had for some time been 'obsessed by what was happening over in Israel'. This certainly helped to bring him closer to Levinas. ${ }^{5}$

If it is true that the question of Palestine-Israel is more of an obsession than an interest for Derrida, then it would follow that another legitimate strategy for 'how to show' the career of Derrida among the Palestinians would be the riskier and altogether more 'radical' gesture of actually reading what Derrida has to say on this topic, noting that this articulation from 1974 is historically specific to his then friendship with Genet 
but bears a relation to other declarations that Derrida later offered on this issue. In so doing, one might not suggest anything as bold as a reading or even a deconstruction of what Derrida might have to say on Palestine. It might be enough at this stage to offer a space in which the clarity of what interests Derrida can be allowed to resound. The question of clarity will be a not inconsiderable stake in the discussion of IsraelPalestine by Derrida, although there may not be a choice to be made between the clarity of Derrida's public pronouncements on Palestine and the seeming complexity of Glas, as if clarity were not a complex thing to negotiate.

For example, one might begin with the comments published at the beginning of 'Interpretations at War: Kant, the Jew, the German' first delivered as a lecture in Jerusalem in 1988, which describe the spirit in which Derrida agreed to participate in the symposium and in others, 'in the occupied territories, with Palestinian colleagues, outside of their universities which were then, and still are, closed by administrative decision (on July 15, 1988), ${ }^{6}$ In this preamble Derrida says (and one might take these words to be definitive of a position):

I had already communicated my anxiety to the organizers of this meeting. I had expressed to them my wish to participate in a conference where Arab and Palestinian colleagues would be officially invited and actively involved. The organizers of this meeting, Professors Sanford Budick and Wolfgang Iser, shared my concern. I thank them for the understanding they have shown in this regard. With all the gravity this requires, I wish to state right now my solidarity with all those, in this land, who demand an end to violence, those who condemn the crimes of terrorism, of military and police repression, and those who advocate the withdrawal of Israeli 
troops from the occupied territories as well as the recognition of the Palestinian's right to choose their own representatives for negotiations that are now more indispensable than ever. This cannot be accomplished without ceaseless, well-informed, courageous reflection. This reflection should lead to new, or not so new, interpretations of what-two years ago, while this conference was being planned here-I had proposed to call the ‘institutions of interpretation’. But that same reflection should also lead us to interpret the dominant institution that is the state, here the Israeli state (whose existence, it goes without saying, must henceforth be recognized by all and definitively guaranteed), along with its prehistory, the conditions of its recent founding, and the constitutional, legal, political foundations of its present functioning, the forms and limits of its selfinterpretation, and so forth. (241)

He goes on to say that this declaration arises not only from a concern for justice and out of friendship for both Palestinian and Israeli colleagues but 'it is meant also as an expression of respect for a certain image of Israel and as an expression of hope for its future' (242). He notes that such 'courageous' historical reflection on the idea of Israel and its future is inscribed in the most strictly determining context of our meeting. It constitutes in my view its very meaning—and its urgency’.

This passage offers in as plain an idiom as one will find in the whole of Derrida (certainly in contrast, say, to either column of Glas) a statement of an interest, in every possible sense, that is always urgent. It might be summarized as a refusal of all positions of violent totalitarianism, the affirmation of Palestinian self-determination, an unconditional guarantee of the state of Israel, and the recovery of a 'certain image' 
of the socialist origins of the Israeli state in contrast to its present militarized and oppressive form. This considered, relatively late, position on the part of Derrida may or may not map onto the articulations of Genet in his writing from the 1970s and early 1980s. One should not take the fact of a friendship as proof of a political or intellectual correlation, or even of a confluence of interests.

There would be much to pick out here before passing on but to go too quickly, in order to develop Derrida’s position, one might look to the conversation with Elizabeth Roudinesco, 'Of the Anti-Semitism to Come' in For What Tomorrow.... Here he offers the following, which again should be quoted at length:

An anecdote: Some time ago, someone I didn’t know called me on the telephone. From the Centre de Documentation Juive: 'My son is writing a thesis on Israel at the Sorbonne. He heard that you were in Tel Aviv two years ago and that you gave a "speech" which the Israeli press reported on. He would like to get a copy.' I didn’t give a lecture in Tel Aviv, I told her; rather I spoke, in front of a large audience and as part of a discussion, about what I thought of the situation and the political stakes, and notably what I disapproved of in Israeli politics. I did so carefully, politely, I believe, but frankly and firmly. Since I had no legible trace of this improvisation, aside from a brief introduction, I told my interlocutor that if her son was interested in what I think of Israel he could find what he's looking for in certain texts of mine [MMQ’s italics]. In general, I added, although the conditions of the foundation of the state of Israel remain for me a tangled knot of painful questions that I could not possibly address over the phone (and even if it is considered a given that every state, that 
every foundation itself is founded in violence, and is by definition unable to justify itself), I have a great many reasons to believe that it is for the best, all things considered, and in the interests of the greatest number of people, including the Palestinians, including the other states in the region, to consider this foundation, despite its originary violence, as henceforth irreversible-on the condition that neighbourly relations be established either with a Palestinian state endowed with all its rights, in the fullest sense of the term, 'state' (at least insofar as anything remains of this full sense and of sovereignty in general; another very serious question I must leave aside for now while briefly relating, in an interview, a telephone interview), or, at the centre of the same 'sovereign' and binational 'state', with a Palestinian people freed from all oppression or from all intolerable segregation. I have no particular hostility in principle toward the state of Israel, but I have almost always judged quite harshly the policies of the Israeli governments in relation to the Palestinians. I have often said so publicly, in particular in Jerusalem, for example, in a lecture I gave quite a long time ago, which was published in more than one language, during the period when one spoke of 'occupied territories' etc. After a few more sentences along these lines, I heard on the other end of the line: 'I see. Well, that's what I suspected. ${ }^{7}$

Despite their lack of understanding and their pre-judgment, one can at least be grateful to Derrida's unnamed telephonic interrogator, for we have here another explicit account of his position (not a neutral term in Derrida ${ }^{8}$ ) on the place of IsraelPalestine: an affirmation of demilitarization, the irreversibility of the foundation of the state of Israeli (justified through a logic of 'for the best', of the least bad 
outcome $^{9}$ ) and an articulation of the necessity of either a two-state solution with full sovereign Palestinian rights or a single 'binational' state solution in which Palestinian citizens share equal rights in a shared sovereignty, ${ }^{10}$ without allowing the violence of present and past Israeli governments to pass without criticism and reproach. He goes on to tell Roudinesco that his conversation with the mother of the Sorbonne student continued:

You no doubt know that I am Jewish; I can feel a deep compassion, even a certain solidarity with the inhabitants of this region and with the historical victims (Jewish and Palestinians) of the atrocities of these times. But I insist on having the right to criticize all the governmental policies, including those of the great powers, dating from before and ever since the foundation of the state of Israel. I do not believe I am giving in to any anti-Semitism by saying this, and, as I have written elsewhere, I even dare to be more faithful than ever to a heritage, a demand for justice that some, rightly or wrongly, do not hesitate to consider essentially Jewish. (FWT119)

If we have allowed Derrida to speak on this topic, quoting at length without the usual academic protocol of the cut or the summation, it is to show or represent (for the question here is 'how to show this?') the direct idiom in which Derrida is both precise and clear on his interest in this matter. One might note the difference in tone between the way in which Derrida speaks on this topic and other moments in Derrida's writing, which we might identify with either a more philosophical or literary vocabulary. In this sense, the interest and the urgency, that returns again and again as if it were an obsession, is a considered articulation of what Derrida means when he 
talks of the sovereign, the state, the Judaic, the Abrahamic, and so on in other contexts. ${ }^{11}$ The interest that might distinguish Derrida from other thinkers from the Arab world might be his adherence to the need to affirm and guarantee the foundation of the Israeli state but he is equally open to either a redefinition of its borders or a more complex sharing of sovereignty between two self-determined peoples. Far from being a 'Heideggerian quietist' position, this is in reality a more meaningful and bolder statement than you will find in many of Derrida's Parisian peers or western governments and even the United Nations. ${ }^{12}$

Derrida concludes his discussion with Roudinesco by noting that he cannot elaborate this problematic further but he has written about it elsewhere. One might think of the text on Sartre in Judeities, the postcard from Ramallah in Counterpath, and 'Message de Jacques Derrida' (Message from Jacques Derrida), his contribution, as part of a delegation of the International Parliament of Writers invited to the Occupied Territories in the spring of 2002, which first appeared in the collection of essays Le Voyage en Palestine in 2002. ${ }^{13}$ There is also the late text 'Avowing-The Impossible, 'Returns', Repentance, and 'Reconciliation: a lesson’ first given as a lecture at UC Santa Barbara in 2003. As Derrida develops the idea of the 'vivre ensemble' [living together] one could cut almost at random into this essay to evidence or represent the continued consistency and elaboration of Derrida's clearly articulated thought on Palestine and Israel. He writes of his Algerian childhood, his experiences of antiSemitism but also his ambivalence to both Algerian nationalism and French occupation as appropriation of the place:

It pushes the said child not only to oppose, sometimes publicly, the politics of the current Israeli government and of a great number of those that preceded it, but also to continue to interrogate himself in the most insomniac fashion regarding the conditions in which the modern state of 
Israel established itself. If there is a place where I do not have the right to hide this, it is here. I hasten immediately to add at least two things: (1) That one can remain radically critical in this regard without implying thereby any threatening or disrespectful consequences for the present, the future, and the existence of Israel, on the contrary; (2) that I have been able to perceive, and to rejoice at this during my last visit to Israel and to Palestine, that these questions, these 'returns' (reflections, repentances, conscious realizations) upon certain founding violences are today more frequent and declared by certain Israelis, citizens and authentic patriots, and by new historians of the state of Israel, the ones and the others having decided to draw political consequences from this return to the past, as some Palestinians do as well. ${ }^{14}$

Once again we witness the solidarity with scholars in Israel and Palestine prepared to question and to criticize the received violence of the state of Israel and of the state of its history, without giving up on the possibility of a recovery of the opportunity afforded by the founding promise of that state. This is the place Derrida occupies, his occupied territory as it were around the question and interrogation of the state, in every sense, of Israel. The interest is clearly stated over three decades in public writing that is significant in its clarity and precision. 'I know that what interests me always takes (its/his) place over there, but how to show that?' One way to show it is sometimes the most obvious, by an unambiguous public articulation; the irony of which might be, given the seeming confusion entertained by many on this topic, that the best way to obscure something is not to inter or bury it, but to hide it in plain sight. $^{15}$

If we were to ask what interests Derrida about this place, the answer is 'clear', even if the politics of the Middle East are anything but 'clear'. It would seem that the greater the opacity, and the greater the concentration and entanglement, the clearer Derrida's prose becomes. In the face of increasing mediatic obfuscation and political complexity, Derrida's writing on this topic retains a commitment to precision. This 
may appear at first glance to be another kind of Derrida, one who speaks clearly as if to avoid the absence of doubt. It might be said that doubt is the place of deconstruction, the cultivation of doubt, that holds open the possibility of questioning the given. However, a commitment to doubt does not have to be imprecise. On the contrary, such a dedication to doubt as a principle requires a rigorous logic and philosophical exactitude. For the absence of doubt, deconstruction adheres to the necessary possibility of doubt. This would be a deconstruction that also doubted the possibility of doubt; it might say 'doubt, if there is any'. By placing doubt in doubt it would trouble the place of doubt as the proper place of a deconstruction. Doubt, if it were to be thought or practised, would not necessarily be defined in relation to ambiguity, uncertainty, obscurity or caveat (categories used to qualify or clarify doubt). Rather, a doubt worthy of the name would be ruined from the start by this commitment to clarification that clearly rests in its transparent centre. An adherence to doubt cannot then be reduced to a question of style; rather style or rhetoric itself is both the avowal of doubt and its clarification, the undoing of doubt by its own clarity. There is then no choice to be made between the Derrida of Glas and the Derrida of his writing on 'Israel-Palestine', whatever interests him takes its place over there.

If we were to ask what is Derrida's interest in this place, that might prove a more difficult interrogation. Towards the end of 'Avowing - The Impossible' he writes of his visit to the cemetery in Jerusalem in 1982, a date close to Genet's work on Prisoner of Love. At the cemetery the officials make decisions about who has the right to be buried in Jerusalem and take calls and offers of money from all over the world, notably the United States. Even before the epoch of digital telecommunication it was clear to Derrida on this occasion that Jerusalem was a switchboard for a global 
conjuration that matched the task of living together with the prospect of dying together and even rising again together. He notes:

New York could appear closer than Gaza (with or without airport), and I could have the feeling of being closer to some other at the other end of the world than to some neighbor, some friend from West Jerusalem or East Jerusalem. To ask oneself then, on a cell phone, whether Jerusalem is in Jerusalem, is perhaps no longer to trust, like others in older times, the distinction between earthly Jerusalem and heavenly Jerusalem. Yet this place of promise appeared to resist substitution and telecommunication. What was signified then, by the placing of this 'taking place' [l'emplacement de cet 'avoir lieu']? And of this messianic taking-place?

But I asked myself first, in anguish—and it was the same question: Who can allocate places? Who can authorize himself, while avowing it, to grant here, to refuse there, to grant to one and refuse to the other the chance to make this place his place, to elect it or to believe himself elected to it, be it in order there to bury his dead or there to await some messianic peace, a to-come or a return? (AI41)

When we read these words from Derrida on the place of place in the psychic terrain of onto-thanto-theological-nationalism, and read them back against the 1974 text of Glas on 'what interests me always takes (its/his) place over there', we might consider the importance of place, situation and position in Derrida's thought and political articulations. In a 2009 book, Derrida, Africa and the Middle East, written in the years after Derrida’s death, Christopher Wise characterizes Derrida’s interest in Israel as 'latent Jewish liberalism' that unconsciously privileges Zionism, in particular 
criticizing Derrida's notion of the 'war for the appropriation of Jerusalem' as an effacement of the colonial occupation of the historic city of Al-Quds: 'Derrida's dramatization of religion's recent return (...) fails to respect Christianity and Islam in their irreducible difference from Judaism, a classically imperialist gesture in which the Other is rewritten as a lesser or inauthentic version of oneself.' Or later, 'when Derrida states that "[the war for the appropriation of Jerusalem] is happening everywhere”, he does more than simply indulge in hyperbole, he distorts the basic facts of Palestinian-Israeli history'. ${ }^{16}$ In fact Derrida had already begun to formulate the idea of the war for the appropriation of Jerusalem in Glas, when he writes in the passage with which we began, of the 'limits of a basin, a sea, where there arrive for an interminable war the Greek, the Jew, the Arab, the Hispano-Moor [l'HispanoMauresque]'. Here the basin in questions is both the so-called 'Holy Basin' of the old city of Jerusalem that locates the holy sites common to Judaism, Christianity and Islam, and the Mediterranean basin and sea from where the Abrahamic tradition spreads out as the diaspora of absolute knowledge qua Europe, home to the Greek, the Morrano, and the interminable war of the monotheisms. ${ }^{17}$

Wise is a card-carrying non-reader whose experience of 'reading' Derrida seems to be limited to the opening chapters of Spectres of Marx. ${ }^{18}$ When Derrida speaks of the 'war for the appropriation of Jerusalem', he is referring, as he does in 'AvowingThe Impossible', to a contest and polemos for the appropriation of the idea of Jerusalem as a gesture of global politics in which there are those who feel themselves qualified to allocate places, to authorize themselves, to grant or to refuse to the other the chance to make 'this place' his place, to believe themselves elected to it, of which Christopher Wise's argument would be just another example of the interment of 
thought. Wise is not only a poor reader of the book on Marx but also fails to understand the argument of The Gift of Death [Donner la Mort] from the previous year, 1992.

Wise is not open to doubt, he authorizes himself to economize sacrifice, weighing one suffering against another, in order to put Derrida in his place, and to take his own definitive place in the history of reading Derrida by adopting what might be described as a difficult position, accusing Derrida of subordinating 'non-Jewish peoples, especially Palestinian Christians and Muslims, to [his] own idiosyncratic logic’ (58). In The Gift of Death Derrida outlines a reasoning of sacrifice in which, as David Wills translates it in a famous formulation, 'every other (one) is every (bit) other' [tout autre est tout autre]. This has been most keenly taken up through the example of the cats of Paris, the animal being more fashionable these days in the Western academy than the politics of the Middle East, whereby Derrida asks 'how could you ever justify the fact that you sacrifice all the cats in the world to the cat that you feed at home every morning for years, whereas cats die of hunger at every instant? ${ }^{19}$ In other words, how can you justify attention to the singular or exemplary when there are so many equally or even more worthy examples of suffering that have a call on our responsibility to act? This is a powerful provocation that does not dismiss the absolute sacrifice to the other but recognizes the imperative duty that binds us to the other as singularity 'in favour of another absolutely imperative duty binding me to every other'. It is the starting point for, say, Derrida's thinking on the Shoa or Auschwitz that does not belittle the examples but considers it no more exemplary than any other example in a necessary general thinking of suffering and the political. ${ }^{20}$ 
The Gift of Death, immediately prior to the often-cited short passage on cats, offers a clear and more significant example of this logic, spread over several pages, as the question of the appropriation of Jerusalem, characterized as just one of 'all the Mount Moriahs of this world' (68) a place where the self-declared elect feel authorized to calculate and measure the value of individual sacrifice in a clear and transparent way, where precision becomes calculation. It would be cathartic for Christopher Wise to read what Derrida actually says:

According to 2 Chronicles, 3 and 8, the place where this occurs, where the sacrifice of Abraham or of Isaac (and it is the sacrifice of both of them, it is the gift of death one makes to the other in putting oneself to death, mortifying oneself in order to make a gift of this death as a sacrificial offering to God) takes place, this place where death is given or offered, is the place where Solomon decided to build the House of the Lord in Jerusalem, also the place where God appeared to Solomon's father, David. However, it is also the place where the grand Mosque of Jerusalem stood, the place called the Dome of the Rock near the grand Aksa mosque where the sacrifice of Ibrahim is supposed to have taken place and from where Muhammad mounted his horse for paradise after his death. It is just above the destroyed temple of Jerusalem and the Wailing Wall, not far from the Way of the Cross. It is therefore a holy place but also a place that is in dispute, radically and rabidly, fought over by all the monotheisms, by all the religions of the unique and transcendent God, of the absolute other. These three monotheisms fight over it, it is useless to deny this in terms of some wide-eyed ecumenism; they make war with fire and blood, have always done so and all the more fiercely today, each claiming its 
particular perspective on this place and claiming an original historical and political interpretation of Messianism and of the sacrifice of Isaac. The reading, interpretation, and tradition of the sacrifice of Isaac are themselves sites of bloody, holocaustic sacrifice. Isaac's sacrifice continues every day. Countless machines of death wage a war that has no front. There is no front between responsibility and irresponsibility but only between different appropriations of the same sacrifice, different orders of responsibility, different other orders... Sacrificial war rages not only among the religions of the Book and the races of Abraham that expressly refer to the sacrifice of Isaac, Abraham, or Ibrahim, but between them and the rest of the starving world, within the immense majority of humankind and even those living (not to mention the others, dead or nonliving, dead or not yet born) who don't belong to the people of Abraham or Ibrahim, all those others to whom the names of Abraham and Ibrahim have never meant anything because such names don't conform or correspond to anything. (69-70)

This is anything but 'latent Jewish Liberalism', whatever that might mean. It is a radical challenge to thinking that both identifies the war for the appropriation of Jerusalem as exemplary of a global war to appropriate the secret of sacrifice and so the right to measure and compare individual suffering, and is itself an effect of that war in which the monotheisms of Islam, Judaism and Christianity use the exemplarity of the contest for Jerusalem to wage war on others on other Mount Moriahs of the world. This is not to say, that for Derrida Jerusalem-Al-Quds is merely an instance for reflection, dismissible as 'faults on both sides', leading to a wider philosophical truth. 
Rather, this argument that is central to much of Derrida's writing from here on in, should be read alongside the passages and texts quoted above on the singularity and historical specificity of moments in the history of two peoples occupying one place in which there is no front between responsibility and irresponsibility, only the absolute irresponsibility of taking responsibility for that place over others and the risk of a total irresponsibility that measured one other's suffering more worthy than the other.

Derrida does not fail to mention the sacrifice of Isaac by Abraham in Glas. One can find here in the Derrida of 1974 one of the most arresting sentences to be found in his entire corpus when he writes apropos of Isaac and Abraham, 'Circumcision and the sacrifice of Isaac are analogous gestures' (E42a). What follows in Glas is a rich reading of Genesis 22 in relation to Hegel's own account, which if followed in its entirety would give rise to another full paper as yet another necessary gloss on Glas. To go too quickly in order to sketch out a familiar Derridean schema taking preliminary shape in 1974, both circumcision and sacrifice appear under the sign of castration; 'both signify the curtailing, the cut, the transcendence, the absence, the subordination of love' (E42a). For Derrida all this 'stands out clearly [tranché]' in Hegel's reading, which offers castration as an 'economic simulacrum' that gives rise to the general conceptual structure of the Aufhebung. At stake in the progression of Hegel's thought on the structure of castration is the fate of the idealism of speculative dialectics. One might wish to intervene in this account of 1974 to suggest that while analogous in the thought of a Hegel, circumcision, sacrifice and castration are not straightforwardly the same thing or even equivalent things in the more fully developed reading of the binding of Isaac that we find twenty years later in Derrida's The Gift of Death. In an economy of sacrifice (and interrupted sacrifice at that) 
between circumcision, castration and oblation, one can take one's pick without necessarily escaping a conceptual order but nevertheless the depth of the cut offers different possible outcomes. For Hegel, Abraham's service to God leads to the reconstitution of a family 'which has become much stronger-and an infinitely privileged nation, raised above the others, separated from the others. But the privilege of this mastery stays abstract, thus simultaneously inverts itself into its contrary: the privilege implies an absolute slavery with respect to God, an infinite heteronomy. The Jewish reign is a reign of death; it destroys the life of other national families, commands from out of its very own death, symbolized by the submission to a transcendent, jealous, exclusive, miserly, presentless god' (E44a). The unhappy consciousness of the Jewish multitude for Hegel isolates the nation around the demand to be alone with their God, and in so doing does not easily reserve the immeasurable for itself but instead only serves to recognize the equal rights of others and their gods as nations outside of itself. How clear any of this is in Hegel is open to question, although it is clearly one of the many things that interests Derrida in the place of Israel-Palestine. As with the writing on Palestine we recognize as idiomatically different to Glas, Derrida's intent here in reading the path of the dialectic through the story of Abraham is not merely to question a concept but to 'question the form of the question that is arranged in the conceptual instance in general' (E44a). In Glas this takes the form of a matrixial deconstruction of Hegel and Genet across two columns as the undoing of the ambition of absolute knowledge; in the writing on Palestine it takes the form of a precise questioning of a singular place that offers the resources of the aporia of clarity and doubt as a further resistance to absolute ambitions. There may be a difference in how Derrida chooses to show 'what remains' in both texts but the gestures are similar, as he writes in Glas: 'forces 
resistant to the Aufhebung, to the process of truth, to speculative negativity must be made to appear [how to show it?], and as well that these forces of resistance do not constitute in their turn relievable or relieving negativities' (E43a). What remains within the dialectic as the fundamentally undialectisable, and how to show it, are stakes that run across all the idioms of Derrida's writing, finding a place of singular interest in the question of Palestine and everything that falls out from it, which is to say a great many things.

In his essay on Genet, Said writes 'There is a brief allusion in Glas to our encounter at Reid Hall in Paris, although I've always been slightly miffed that Derrida should refer to me only anonymously, as "un ami” who brought him news of Genet." ${ }^{21}$ It is not clear why Said is 'miffed'. Is it because he wanted to be cited in Glas, avowed as it were, given his place or given his place back to him, identifying the question of Palestine as his place, as part of the Genet-Said story, in preference to being buried in the text having had his name sacrificed for anonymity (arrested, drawn back, bridled)? Or is it because in writing Glas and writing back to Sartre's appropriation of Genet for existentialism Derrida seems in his own way to appropriate Genet and the Palestinians for himself? In this sense, Glas would represent something of a philosophical land grab on Derrida’s part. Something that Derrida recognizes in his own commentary, in a moment in which he returns late in the column to the mode of address we first encountered in our opening passage:

He will be furious with me [m'en vouloir à mort] for all sorts of reasons I will not take time to enumerate. And at all events and cases. If I support or valorize his text, he will see in this a sort of approbation, verily of 
magisterial, university, paternal or maternal appropriation. It is as if I were stealing his erection from him. (E199b)

In the absence of Genet, Derrida, and Said, we can only speculate on this purloined phallus and what becomes of it when it is passed from hand to hand. Perhaps, to be prosaic, Derrida's reticence in naming names here is predicated on the most ethical of motives in a time of danger in the career of a Genet and the Palestinian cause. However, equally, and I would suggest more compellingly, if there is an allusion in Glas to this meeting between Derrida and Said then it is a very well-hidden one. I have read and re-read the right-hand column searching for it but the scene does not seem to exist (I accept the possibility that my own reading might be willfully blind to the faux-amis). I can find no reference to news delivered by a friend on the whereabouts of Genet. This suggests either that Said had not actually read Glas and is referring here to something reported to him by 'a friend', or, that in writing his text on Genet, Said is mis-remembering the exact nature of the allusion in Glas. This might lead us to speculate that Said may in fact be referring to the very passage with which we began. Here Derrida does not say that he had spoken to Genet, but rather that 'he let me know' [il m'a fait savoir] that he was in Beirut. This is as close as we get in Glas to a suggestion of a communication between Genet and Derrida. Perhaps, to speculate, Edward Said was the facteur who delivered a message from one to the other, with Said's memoir offering itself as the place where this destinerrance takes its place, the site in which the letter arrives otherwise. Perhaps Glas, despite appearances, is also a place in which the letter of Genet arrives in another context: 'if I write for his text, I write against him, if I write for him, I write against his text. The friendship is irreconcilable' (E200b). Such moments of meta-commentary characterize both columns of Glas; in the case of Genet there is a specific context in 
which Derrida is stealing the genie from Sartre's cave of wonders, and according to Said, disavowing a specific route of escape. However, the Derrida of Glas seems to be fully aware of the possibility of a reading that establishes a misreading that upholds the rigor of truth: 'do I write for him? What would I like to do to him? Do to his “work”? Ruin it by erecting it, perhaps’. In appropriating a certain Genet, Derrida appears to be fully aware that the academic and philosophical monumentalisation of Genet, by what he called in his Jerusalem address the 'institutions of interpretation', is the ruin of the writer and the thief, turning pleasure into work, to undo unto others as one would undo unto one's self, perhaps; one might reflect, for example, on the peeling monument of Derrida Studies today. Equally, we recall that whatever happens in his/its place, interests Derrida. The one who is repeatedly concerned by the otherwise, including the socialist, other origins of Israel.

There is no place to land here, other than that explicitly, singularly, clearly, laid out by Derrida in a radical transparency. Such a space is not without complication or doubt. When so much is at stake in the North American academy, which is to say the global academy, metonymically speaking, today, one might say that the question of Israel-Palestine and its deconstruction remains essential today beyond a simple either/or, and beyond a simple 'Derrida says', but must be rather the living place of a theoretical practice that we have come to recognize in reading Derrida among the Palestinians.

\section{Notes}

\footnotetext{
${ }^{1}$ Jacques Derrida, Glas, translated by John P. Leavey, Jr. and Richard Rand (Lincoln and London: University of Nebraska Press, 1986), 36-7b. Hereafter cited in the text, preceded by the initial E.
} 
${ }^{2}$ Jean Genet, Prisoner of Love, translated by Barbara Bray (New York: New York Review of Books, 2003).

3 Edward Said, 'On Jean Genet's Late Work', Grand Street Magazine 36 (1983), http://www.grandstreet.com/gsissues/gs36/gs36c.html; consulted on 5 March 2016.

${ }^{4}$ Edmund White, Genet: A Biography, (New York: Vintage, 1993), 566 and 572.

${ }^{5}$ Benoit Peeters, Derrida: A Biography, translated by Andrew Brown (Cambridge: Polity Press, 2012), $\mathrm{x}$.

${ }^{6}$ Jacques Derrida, 'Interpretations at War: Kant, the Jew, the German' trans Moshe Ron, in Psyche: Inventions of the Other, vol. 2, edited by Peggy Kamuf and Elisabeth Rottenberg (Stanford: Stanford University Press, 2008), 241. Psyche: Inventions of the Other,

${ }^{7}$ Jacques Derrida and Elizabeth Roudinesco, For What Tomorrow...: A Dialogue, translated by Jeff Fort (Stanford: Stanford University Press, 2004), 118-9. Hereafter cited in the text, preceded by FWT. ${ }^{8}$ See Jacques Derrida, Positions, translated by Alan Bass (London: Athlone Press, 1981) and Jacques Derrida, Points... Interviews, 1974-1994, edited by Elisabeth Weber (Stanford: Stanford University Press, 1995).

${ }^{9}$ On the logic of least violence, see Jacques Derrida, 'Violence and Metaphysics: An Essay on the Thought of Emmanuel Levinas' in Writing and Difference, translated by Alan Bass (London: Routledge \& Kegan Paul, 1978).

${ }^{10}$ On the question of the one-state solution see, among others, Edward Said, 'Truth and Reconciliation', Al-Ahram Weekly, 14 January 1999; Edward Said, The End of the Peace Process: Oslo and After (London: Granta Books, 2000); Virginia Q. Tiley, The One-State Solution: A Breakthrough for Peace in the Israeli-Palestinian Deadlock (Manchester: Manchester University Press, 2005).

${ }^{11}$ On sovereignty in Derrida, see The Beast and the Sovereign, vols. 1 and 2, translated by Geoffrey Bennington (Chicago: Chicago University Press, 2009 and 2011); Jacques Derrida, Rogues: Two Essays on Reason, translated by Pascale-Anne Brault and Michael Naas (Stanford: Stanford University Press, 2005); Jacques Derrida, Sovereignties in Question: The Poetics of Paul Celan, edited by Thomas Dutoit and Outi Pasanen (New York: Fordham University Press, 2005).

${ }^{12}$ For an account on Edward Said's 'disappointing' discussions with Jean-Paul Sartre, Simone de Beauvoir and Michel Foucault on Israel-Palestine, see 'Diary’, London Review of Books, vol. 22 no.11, 1 June 2000. 
${ }^{13}$ See Judeities: Questions for Jacques Derrida, edited by Bettina Bergo, Joseph Cohen and Raphael Zagury-Orly, translated by Bettina Bergo and Michael B. Smith (New York: Fordham University Press, 2007); Catherine Malabou and Jacques Derrida, Counterpath: Travelling with Jacques Derrida, translated by David Wills, (Stanford: Stanford University Press, 2004); Le Voyage en Palestine, edited by Banks, Breytenbach, Goytisolo et al. (Castlenau-le-lez : Editions Climats, 2002), 123-36.

${ }^{14}$ Jacques Derrida, ‘Avowing—The Impossible: “Returns”, Repentance, and Reconciliation: A Lesson’ in Living Together: Jacques Derrida's Communities of Violence and Peace, edited by Elisabeth Weber (New York: Fordham University Press, 2013). Hereafter cited in the text, preceded by AI.

${ }^{15}$ On the question of Derrida and Said, and so Palestine more generally, see Caroline Rooney, 'Derrida and Said: Ships that Pass in the Night' in Edward Said and the Literary, Social and Political World, edited by Ranjan Ghosh (New York; Routledge, 2009), pp.36-53; and Martin McQuillan, “"The Last Jewish Intellectual”: Edward Said and the Deconstruction of Palestine' in Deconstruction after 9/11 (New York: Routledge, 2009), pp.145-68.

${ }^{16}$ Christopher Wise, Derrida, Africa and the Middle East (Basingstoke: Palgrave, 2009), 52-4.

${ }^{17}$ On the figure of the Marrano, see Jacques Derrida, 'Abraham, the Other' in Judeities: Questions for Jacques Derrida.

${ }^{18}$ See Jacques Derrida, Specters of Marx: The State of the Debt, the Work of Mourning, and the New International, translated by Peggy Kamuf (London and New York: Routledge, 1994), 50.

${ }^{19}$ Jacques Derrida, The Gift of Death, translated by David Wills (Chicago: University of Chicago Press, 1994), 70.

${ }^{20}$ See for example, Jacques Derrida and Jean-François Lyotard, 'Discussions, or Phrasing "After Auschwitz”' in The Lyotard Reader, edited by Andrew Benjamin (Oxford: Blackwell, 1989), 360-93.

${ }^{21}$ Edward Said, 'On Jean Genet’s Late Work’. 